\title{
Simulation Study to Evaluate the Performance of a Photovoltaic System Connected to the Electrical Network in the Municipality of Terra Santa - PA
}

\author{
Felipe Ferreira Cavalcante ${ }^{1}$, Vanise dos Santos Rodrigues ${ }^{2}$, Greyce dos Santos Rodrigues ${ }^{3}$, \\ Marcus Vinicius Alves Nunes ${ }^{4}$, Elda Nunes de Carvalho ${ }^{5}$, Wilson Gonçalves de Araújo ${ }^{6}$, \\ Philip Floriano Rodrigues Ramkeerat ${ }^{7}$, Vilmara Souza e Silva ${ }^{8}$
}

\author{
${ }^{1,6}$ Centro University of North - UNINORTE - Manaus - AM - BRASIL. \\ 2,3,4,5,7Federal University of Pará - UFPA - Belém - PA - Brasil. \\ ${ }^{8}$ Institute of Galileo Education Technology of the Amazon - ITEGAM - Manaus - AM - Brasil.
}

Email: Flp_cavalcante@hotmail.com, Vanise_santosrodrigues@hotmail.com, Greyce.gsr@gmail.com, Eldanunes@gmail.com, Wilsonga2@gmail.com, Philip_ramkeerat@hotmail.com, Vilmara.silva@seducam.pro.br

Received: March $13^{\text {th }}, 2017$

Accepted: May $14^{\text {th }}, 2017$

Published: June $30^{\text {th }}, 2017$

Copyright 02016 by authors and Institute of Technology Galileo of Amazon (ITEGAM). This work is licensed under the Creative Commons Attribution International License (CC BY 4.0).

http://creativecommons.org/lic enses/by/4.0/ (c) (1) (9) Opea Acten

\begin{abstract}
Electricity is an important factor in the everyday life of society, and every day consumption is increasing. Besides this fact, there is also the current concern with the preservation and preservation of the environment. This research aims to evaluate, through simulations using PVSOL PREMIUM 2017 software, the power generation of a photovoltaic system connected to the distribution grid. In the simulations it was admitted that the photovoltaic system will be installed in the Terra Santa of Pará with the following geographic coordinates Latitude $-1^{\circ} 22^{\prime} 47$ " and Longitude $-48^{\circ} 28^{\prime} 47$ ". In this system, 10 AXITEC AXPOWER AC-250P / 156-60S photovoltaic modules and a FRONIUS IG 3000 inverter will be used to meet an annual consumption requirement of $4041 \mathrm{kWh}$. Th is study will also allow to know the prediction of income with energy consumption, energy savings after system implementation, inverter efficiency, system performance, time of return of investment and amount of energy injected into the grid of distribution.
\end{abstract}

Keywords: Photovoltaic system, photovoltaic software, photovoltaic design, photovoltaic energy.

\section{Estudo de Simulação para Avaliar o Desempenho de um Sistema Fotovoltaico Conectado à Rede Elétrica no Município de Terra Santa - PA}

\section{RESUMO}

A eletricidade é um fator importante no cotidiano da sociedade, e a cada dia o consumo vem aumentando. Além deste fato, há também a preocupação atual com a preservação e concervação do meio ambiente. Es sa pesquisa vis a avaliar, através de simulações utilizando o software pvsol premium 2017, a geração de energia de um sistema fotovoltaico conectado à rede elétrica de distribuição. Nas simulações admitiu-se que o sistema fotovoltaico será instalado em terra santa interior do pará com as seguintes coordenadas geográficas latitude $-1^{\circ} 22^{\prime} 47^{\prime}$ ' e longitude $-48^{\circ} 28^{\prime} 47^{\prime}$. . Nes se sistema serão utilizados 10 módulos fotovoltaicos modelo axitec axpower ac-250p/156-60s e um inversor fronius ig 3000 para atender uma necessidade de consumo anual de $4041 \mathrm{kwh}$. Es se estudo permitirá conhecer, ainda, a previsão de rendimento com consumo de energia, a economia de energia após implementação do sistema, o rendimento do inversor, o desempenho do sistema, o tempo de retorno do investimento e a quantidade de energia injetada na rede elétrica de distribuição.

Palavras chaves: Sistema fotovoltaico, software fotovoltaico, dimensionamento fotovoltaico, energia fotovoltaica.

\section{INTRODUCTION}

Since April 17, 2012, when the Normative Resolution of the National Agency of Electric Energy - ANEEL N 482/2012 came into force allowing the Brazilian consumer to be able to generate its own electricity from renewable sources or qualified cogeneration and even supply the surplus To your local dis tribution network. These are the micro and the distributed minigeration of 
electric energy, innovations that can ally financial economy, socioenvironmental awareness and self-sustainability [1].

The incentives to distributed generation are justified by the potential benefits that such modality can provide to the electric system. These include the postponement of investments in expansion of transmission and distribution systems, low environmental impact, reduction in network loading, minimization of losses and diversification of the energy matrix [1]. With the objective of reducing the costs and time for the connection of microgeneration and minigeration; To reconcile the Electric Energy Compensation System with the General Conditions of Supply through Normative Resolution N 414/2010, increase the target public; And to improve information on the invoice, ANEEL published Normative Resolution No. 687/2015 revising Normative Resolution No. 482/2012 [1].

This study aims to contribute to the research that uses software to size and evaluate the potential of photovoltaic energy generation. For this purpose, PVSOL PREMIUM 2017 software will be used to evaluate the potential for photovoltaic energy generation that can be produced by a photovoltaic system connected to the distribution grid located in the interior of the Holy Land of Pará with the following geographic coordinates Latitude $1^{\circ} 22$ ' 47 " and Longitude $-4828^{\prime} 47$ ". A preliminary study on residence consumption was carried out, confirming an annual consumption of $4041 \mathrm{KWH} /$ year, paying the concessionaire the equivalent of R \$2987.64. Therefore, the simulations carried out with PVSOL PREMIUM software must meet this consumption requirement. Initially an evaluation of the potential of local solar irradiation was carried out. For this, NREL SWERA NREL SWERA software was used at [2], where it was possible to obtain information on solar irradiation and temperature for Terra SantaPA.

To meet the need for consumption, 10 photovoltaic modules of the company AXITEX model AXPOWER AC-250P/ 156-60S and a FRONIUS IG 3000 inverter were used in the simulations. In the simulations it was admitted that the ten modules were connected in series and the software PVSOL PREMIUM 2017 showed through the graphical results that the implanted system allows a reduction in energy consumption of approximately $70 \%$. Photovoltaic systems are important alternatives to generate energy, helping in a satisfactory way to reduce the billing of energy consumption and contribute in parallel with the emission reduction of the greenhouse gases that are emitted daily in the atmosphere.

\section{LITERATURE REVIEW}

In the last decades, companies fromdiverse sectors felt the need to mobilize and adopt new policies, due to environmental awareness. Concern about the environment is growing every year, and the collection is not only from the government, but to a large extent the consumers [3]. Non-renewable energy sources are used on a large scale, however the concern that in a horizon of some decades these could be exhausted. Due to this fact, we are looking for new alternatives for the generation of energy at a sustainable level. Photovoltaic technology is one of the renewable resources that is increasingly used in developed countries [4][5].

Solar energy has a very variable behavior and its use in the form of electric energy depends, undoubtedly, on the Power Electronics, a science that has a set of knowledge suitable to make it usefuland competitive. Currently there are researches focused on evaluating the behavior of photovoltaic systems, among which we can mention: A comparative study between photovoltaic energy and conventionalenergy sources was developed by [6]. A research related to the study of photovoltaic energy using the climatic conditions of Portugal was treated in [7][8]. A study on the economical and environmental viability in the use of photovoltaic energy in Brazil is [9] Studies on the use of photovoltaic energy in Brazil was developed [5].

To assist in the design and performance of photovoltaic systems, there are studies that deal with the use of photovoltaic software, which allow to evaluate in advance the behavior of the system and the prediction of the generation of energy produced by the investment. In the solar energy laboratory of the Federal University of Rio Grande do Sul, a computer software was developed to simulate photovoltaic systems connected to the distribution grid called FVConect. With this software were performed mathematical simulations of the components of the photovoltaic system and the comparis on of electric power curves, we also performed experimental correlations obtained from the photovoltaic system installed in the laboratory premises. In order to compare the results, the PVSYST software [10].

The HOMER software was used to evaluate the comparative study of the feasibility of photovoltaic systems connected to the distribution grid [11]. A modeling and simulation of photovoltaic nanorods (NRs) and nanowires (NW) photovoltaic cells that allow estimation of cell performance and characteristics, such as efficiency, fill factor, short-circuit current and circuit voltage Open research was carried out by [12]. A proposed method to predict the economic potential of the integrated photovoltaic system in buildings, based on hourly simulations of irradiation was the focus of studies of [13]. The performance analys is of a networkconnected photovoltaic system in the northeastern region of Brazil developed by [14].

\section{MATERIALS AND METHODS}

\section{III.1 GEOGRAPHICAL LOCATION OF TERRA SANTA-PA}

Terra Santa is a Brazilian municipality in the state of Pará. It is located in the north of Brazil, at latitude $-1^{\circ} 22^{\prime} 47$ "and longitude $-48^{\circ} 28^{\prime} 47^{\prime \prime}$.

The municipality has an estimated population of 20946 thousand inhabitants distributed in $1896 \mathrm{~km}^{2}$ of territorial extension.

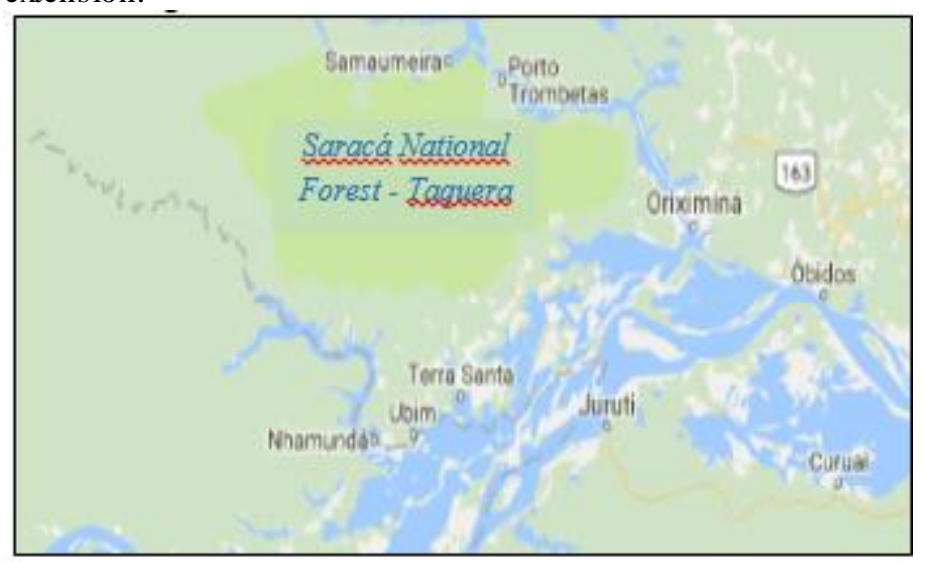

Figure 1: shows the satellite location of Terra Santa. Source: [2].

\section{III.2 IRRADIATION IN THE HORIZONTAL PLANE IN TERRA SANTA-PA}

The solar irradiance data in the horizontal plane presented is obtained by satellite from the NREL SWERA NREL SWERA 
software database at [2] available free of charge on the internet for the geographical coordinates of Terra Santa- PA where the annual irradiation average is $5.06 \mathrm{KWh} / \mathrm{m} 2$.day, which is the hours of Sol Pico (HPS). The graph of Figure 2 shows the irradiation in the horizontal plane in $\mathrm{KWh} / \mathrm{m}^{2}$.day throughout the year in Terra Santa-PA.

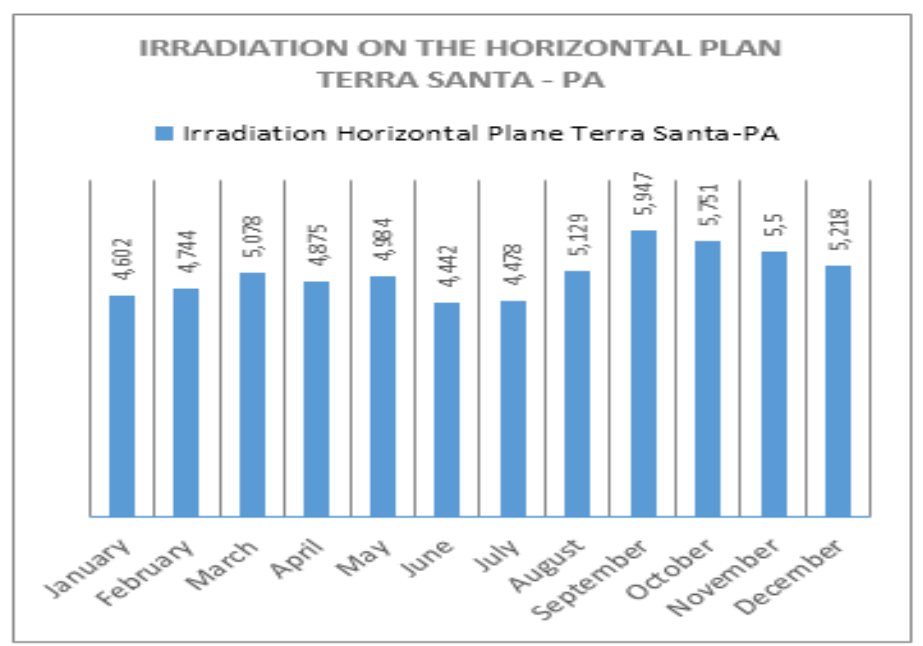

Figure 2: Solar Irradiation in the Holy Land.

Source: [2].

\section{III.3 TEMPERATURE IN TERRA SANTA-PA}

The climate in the Holy Land is tropical. There is only a short dry season and it is not very effective, whereas in most of the months of the year there is a significant rainfall. September is the driest month with $43 \mathrm{~mm}$. Presenting an average of $399 \mathrm{~mm}$, the month of March is the month of greatest precipitation, with the average annual rainfall of $2358 \mathrm{~mm}$. Temperature data were obtained by satellite from the NREL SWERA software database at [2]. The graph of Figure 3 shows the monthly temperatures in Terra Santa-PA. It is observed that in the months of August, September, October and December the temperatures are higher. Being that the highest peak of temperature occurs in the month of September $29,8^{\circ} \mathrm{C}$ and the smallest peak of temperature occurs in the month of April $25.68^{\circ} \mathrm{C}$.

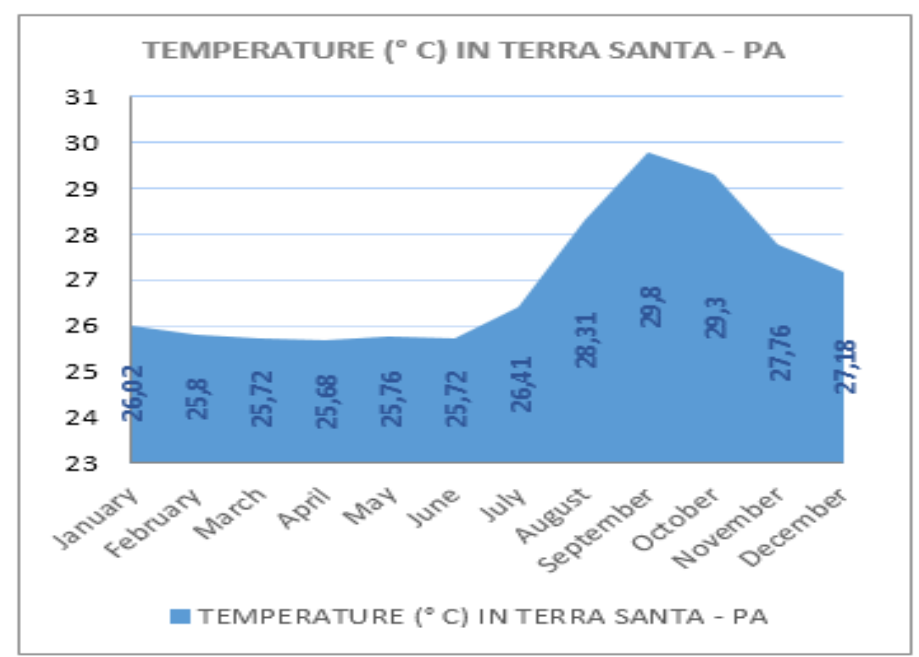

Figure 3: Monthly Temperature in the Holy Land. Source: [2].

\section{III.4 HISTORICAL ENERGY CONSUMPTION DATA}

The historical data of the energy consumption is obtained from the operator CELPA that provides the annual consumption of the residence under study. Having the information of energy consumption it is possible to carry out the sizing of the system to meet the need of the residence. Figure 4 graphically shows the monthly consumption of the study residence. It is observed that the highest consumptions are in the month of June, October, November and December. The annual consumption corresponds to $4041 \mathrm{KWh}$ /year.

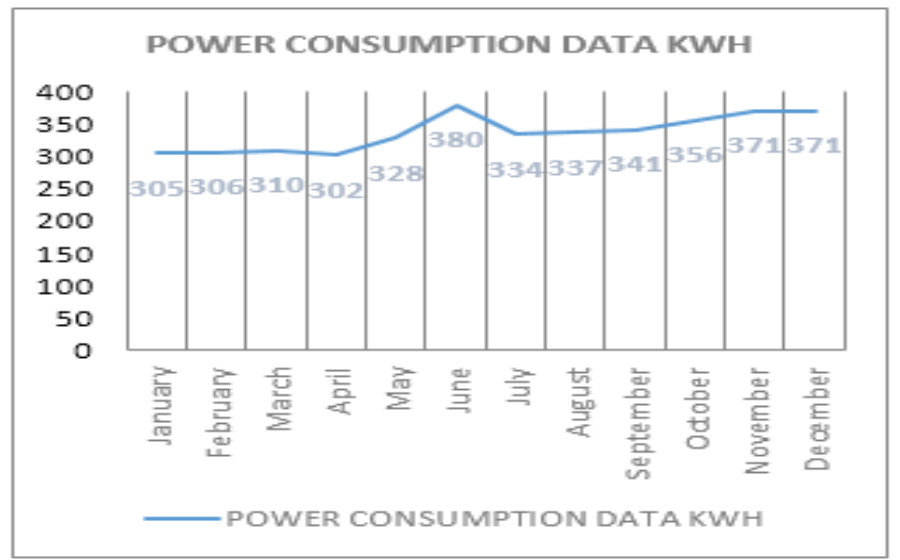

Figure 4: Monthly Consumption of Residence in Study.

Source: Authors, (2017).

\section{III.5 TYPES OF PHOTOVOLTAIC SYSTEMS - ISOLATED SYSTEMS}

Is olated or autonomous systems are alternatives considered attractive and economically viable to generate electricity for communities in remote locations, that is, distant from the distribution network. They are distributed generation systems that do not have any communication with the electricity grid of the concessionaire. Generally, energy storage components are used by batteries in order to allow the generated energy to be subsequently used in periods of low solar irradiation or at night. To control the charge and discharge of the battery is used the charge controller, which has the function of not letting damage to the battery by overcharge or deep discharge. The load controller is used in small systems where the devices used are low voltage and direct current (DC). Some is olated systems do not require storage, which is the case of irrigation, where all pumped water is directly consumed or stored in reservoirs. For powering alternating current (AC) equipment an inverter is required [15].

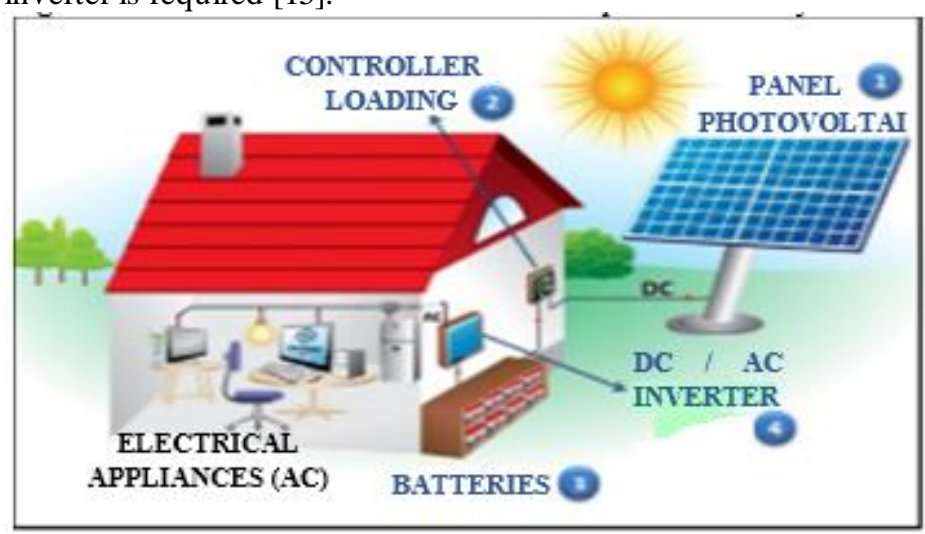

Figure 5: shows the scheme of an is olated photovoltaic system. Source: [16]. 


\section{III.5.2 HYBRID SYSTEMS}

Hybrid systems of electric power generation are systems formed by two or more sources of energy production, operating together to meet the demand of a common consumer, as shown in Figure 6.

The average consumer refers to a community or locality, served through a mini distribution network. The most commonly used energy sources in this type of system are solar and wind.

The use of various forms of electric power generation becomes complex in the need to optimize the use of energy, therefore, it is necessary a control of all sources for maximum efficiency in the delivery of energy to the consumer.

It is worth mentioning that this system can present an inverter at the output of the photovoltaic modules. Within this field of application, hybrid systems can be classified from medium to large [17].

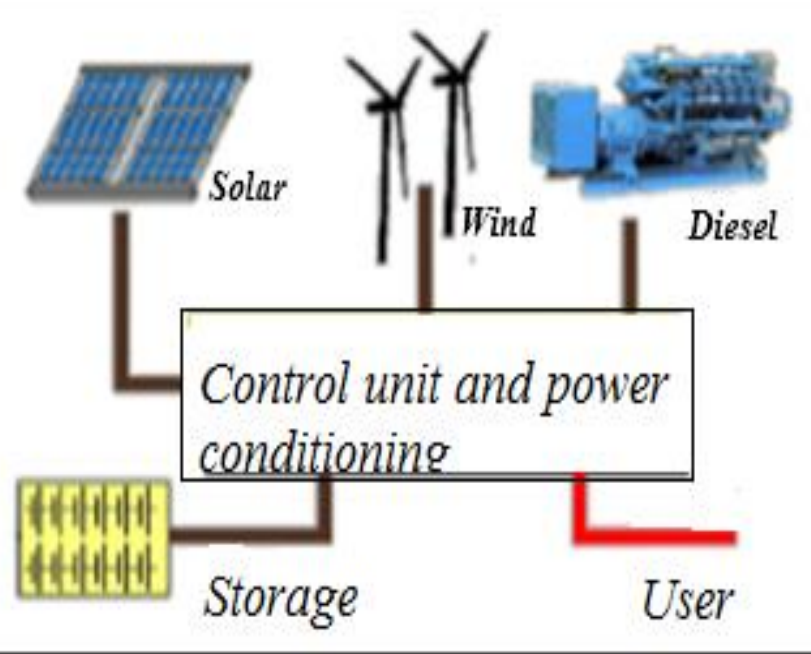

Figure 6: Hybrid photovoltaic system. Source: [18].

\section{III.5.3 NETWORK CONNECTED SYSTEMS}

Distributed photovoltaic systems connected to the grid are installed to provide power to the consumer, who can use the power of the conventional grid to supplement the amount of energy demanded if there is any increase in the energy consumption in his residence or commercial establishment.

Figure 7 shows a schematic representative of this configuration. The consumer can make the free loan of the energy generated to the distributor if it is not consuming, ie, does not need banks of batteries to store energy, the grid itself is the "energy store" of the system, thus, the loan made Is offset by the active power consumption.

The entire arrangement is connected to voltage inverters, which must meet the requirements of product quality and safety so that the network is not affected, such as anti-islanding and harmonic distortion.

Photovoltaic systems connected to the grid (SFCR) can be large (photovoltaic) or small (decentralized and installed in urban buildings ) [19].

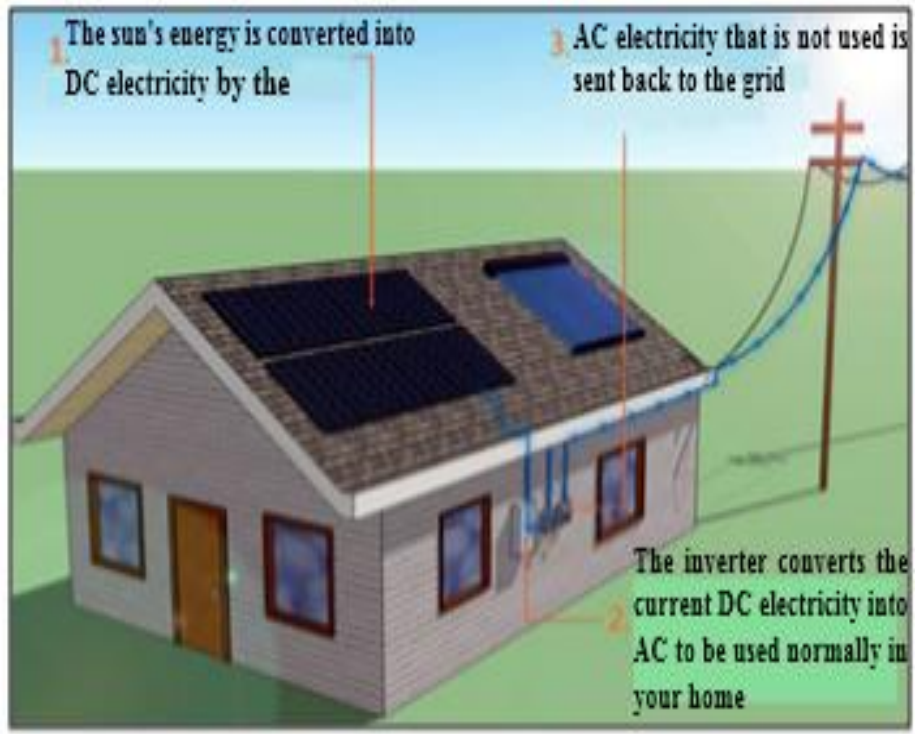

Figure 7: Photovoltaic systemConnected to the grid. Source: [16].

\section{III.6 COMPONENTS OF A PHOTOVOLTAIC SYSTEM}

Photovoltaic systems: Photovoltaic panels, Charge controllers, Inverters and connection fittings.

Solar Panels - They play the role of heart, "pumping" energy into the system. They can be one or more panels and are sized according to the energy required. They are responsible for turning solar energy into electricity.

The efficiency of the photovoltaic module is given by the relation between the maximum power of the module divided by the product of the area occupied by the module and the standard irradiation STC, which allows to evaluate the national and international certification criteria.

The ratio (1) is used to determine the efficiency of the photovoltaic module is given according to [20]:

$$
\eta_{p v}=\frac{P_{M A X}}{A p \times 1000} \times 100
$$

Onde:

$\eta_{p v}$ : Is the efficiency of the photovoltaic module [\%].

$P_{M A X}$ : Maximum power or peak of the module [W].

Ap: It is the area of the module provided through the mechanical data which are the dimensions of the chosen module $\left[\mathrm{m}^{2}\right]$.

1000: represents STC standardized solar irradiance.

The Figure 8 shows the characteristic curve of the efficiency of the module as a function of irradiation. It is observed that the best efficiencies are presented with the modules operating at low temperatures, within the previously achieved safety range for low temperature design. The efficiency of the AXPOWER AC$250 \mathrm{P}$ module is $15.44 \%$. 


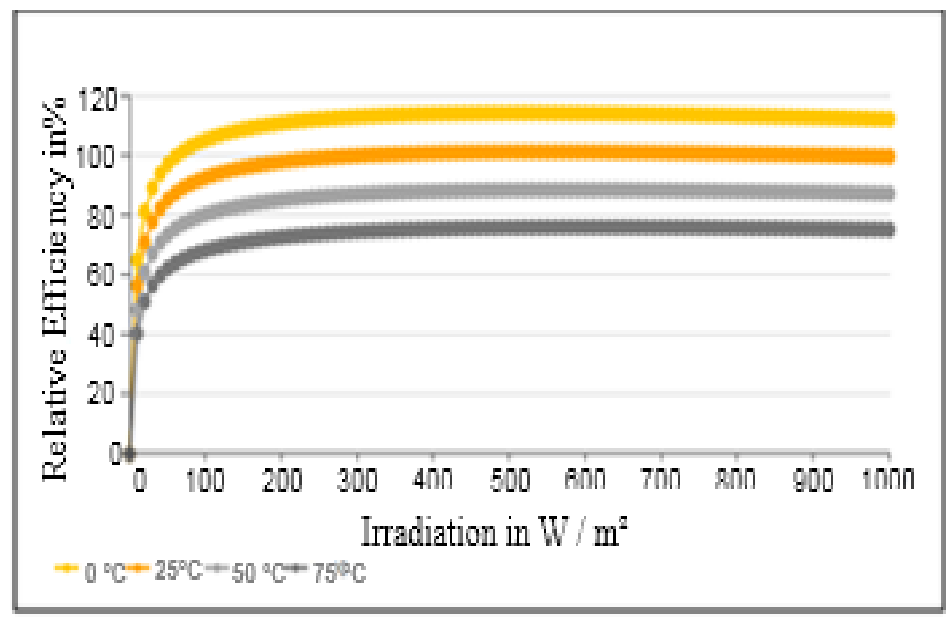

Figure 8: Module efficiency.

Source: [21].

The characteristic curves and voltage under constant temperature show that as the solar irradiation increases the voltage and the current also increases and consequently the power of the module, figure 9 graphically shows the statement.

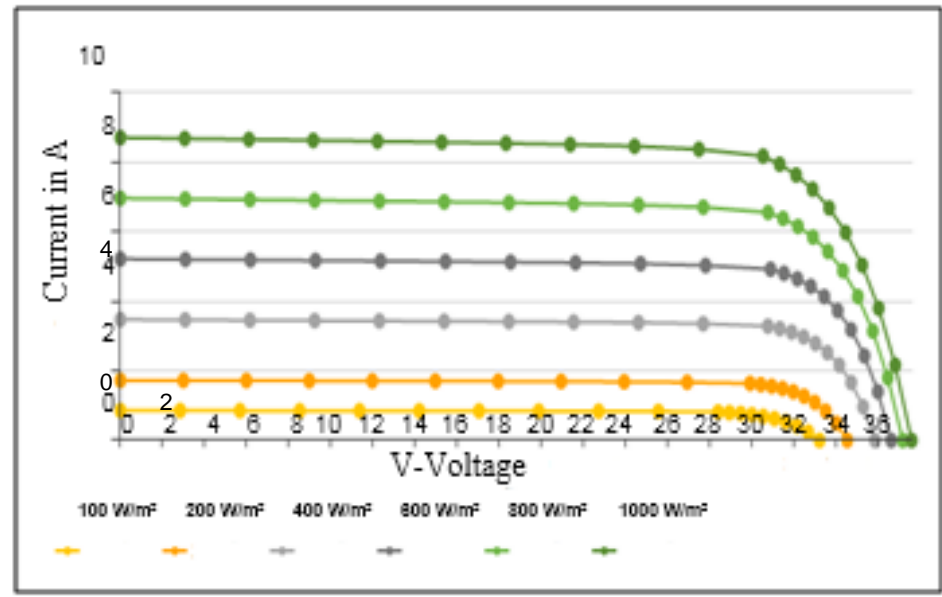

Figure 9: Correct and voltage characteristic curves.

Source: [21].

"Performace Ration" (PR) is the relationship between the theoretical performance and the actual performance of the photovoltaic system. The PRencompasses all systemlosses. In this Survey, a PR equal to $79.4 \%$ is allowed.

The number of modules to be used in a photovoltaic power generation project is given according to ratios 2 and 3, for [22]:

$$
\mathrm{PPEAK}=\frac{\left(E C D * G \_r\right)}{H S P * P R}
$$

At where:

PPEAK: Power of photovoltaic system KWp.

ECD: Daily consumption.

G_r: Reference irradiance $1 \mathrm{KWh}$.

HSP: It is the average hours local sun peak in $\mathrm{kWh} / \mathrm{m}^{2}$.day -1

PR: "Performace Ration" of the System.

PModulo: Power of the chosen module.

$$
M_{o}=\frac{P_{P E A K}}{P_{\text {Modulo }}}
$$

At where:

M_o: It is the amount of modules that should be used in the photovoltaic system.

P_PEAK: Electrical power of the photovoltaic array $[\mathrm{Wp}]$.

P_Module: This is the peak power value of the model module in [Wp] found in the manufacturer's manual (Datasheet) under standard STC test conditions.

For sizing the photovoltaic system it is important to know the electrical data that are provided by the manufacturers.

In the simulations of this study we chose to use the photovoltaic module model AXITEC AXPOWER AC-250P / 156$60 \mathrm{~S}$ made with polycrystalline silicon composed of 60 cells. Its mechanical dimensions are width $992 \mathrm{~mm}$, length $1640 \mathrm{~mm}$, height $40 \mathrm{~mm}$, frame width $11 \mathrm{~mm}$ and weight $18 \mathrm{~kg}$ and the surface area of the photovoltaic module $1.63 \mathrm{~m}^{2}$. Figure 10 shows the layout of the panel dimensions.

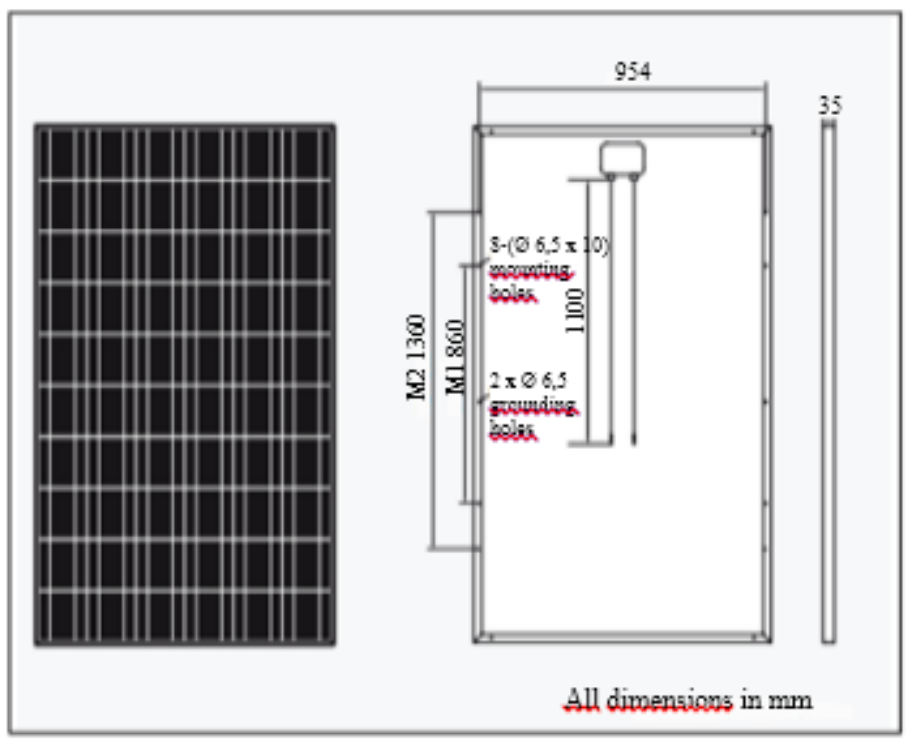

Figure 10: AXITEC AXPOWER AC-250P / 156-60S module. Source: [23].

Working Points on Standard Test Conditions (STC), where the reference temperature is $25^{\circ} \mathrm{C}$ and the reference irradiance is $1000 \mathrm{~W}$. The electrical data of the modules are shown in table 1 .

Table 01: Electrical Data of the AXITEC AXPOWER AC-250P / 156-60S Module.

Electrical module data in STC

\begin{tabular}{l|c}
\hline Voltage at maximu m power Vmpp [V] & 30,7 \\
\hline Current at maximum power Immp [A] & 8,18 \\
\hline Module Power [Wp] & 250 \\
\hline Open circuit voltage Vca [V] & 37,8 \\
\hline Short circuit current Isc [A] & 8,71 \\
\hline Voltage Correction Coefficient C (Vmmp)\% (K)] & $-0,42$ \\
\hline Voltage correction coefficient C (Vca) [\% (K)] & $-0,3$ \\
\hline Short-circuit correction coefficient C (Isc) [\% (K)] & 0,04
\end{tabular}

Source: [23].

$>$ De Load controllers - Operate as valves for the system. They serve to avoid overloading the system. 
$>$ Inverters - The inverter, or DC-AC converter, is the device responsible for converting DC quantities, which are at the output of the solar panel, into AC quantities. This type of conversion is usually necessary since most of the current electrical equipment is powered by $\mathrm{AC}$ voltage. Control of this device is generally performed via pulse width modulation.

In this study we use the relation (2) that was previously defined to indicate the choice of the inverter power to be used in the design of the photovoltaic system.

For the simulations of this study will be used a FRONIUS 3.0 inverter that is recommended to meet a power demand of $2500 \mathrm{Wp}$ to $3300 \mathrm{Wp}$. This inverter displays the voltage range at maximum input power in the range of $150 \mathrm{~V}$ to $450 \mathrm{~V}$ and the maximum DC voltage equal to $500 \mathrm{~V}$. The nominal input voltage is $280 \mathrm{~V}$. The nominal input current is $10 \mathrm{~A}$.

It is important to evaluate the operating conditions of the module at low temperatures and high tempestuaras, in this case the voltages of the photovoltaic array are evaluated. The photovoltaic arrangement may be arranged in series and / or parallel.

In order to evaluate these conditions it is necessary to carry out the correction using the temperature correction coefficients for voltage in Maximum Power.

At high temperatures the ratio (4) is used:

$$
(V M M P)=V m m p+(C(V m m p) * V m m p) *(\Delta t)
$$

At where:

VMMP: is the voltage in Maximum Power corrected in the conditions of high temperatures.

(Vmmp): Coefficient of temperature correction for voltage at maximu $\mathrm{m}$ power.

Vmmp: is the voltage in Maximum Power of the photovoltaic array arranged in series and / or parallel.

$\Delta \mathrm{t}=\mathrm{t}-25$, where $\mathrm{t}$ is the maximu m modulus temperature.

At low temperatures the ratio (5) is used:

$$
(V C A)=V c a+(\mathrm{C}(\mathrm{Vca}) * \mathrm{Vca}) *(\Delta t)
$$

At where:

VCA is the open circuit voltage correction for low temperature.

$\mathrm{C}$ (Vca): is the temperature correction coefficient of the open circuit voltage.

Vca: is the open circuit voltage of the photovoltaic array that can be arranged in series and / or parallel. module.

$\Delta \mathrm{t}=\mathrm{t}-25$, where $\mathrm{t}$ is the minimum temperature of the

The evaluation of the behavior of the photovoltaic arrangement in series or parallel in low and high temperatures is important to verify the adequate range of operation of the inverter chosen to compose the photovoltaic system.

The evaluation of the low temperatures allows to avoid a possible burn of the inverter that can be caused by the increase of the voltage as a function of low temperatures. Therefore, this verification provides security for the sizing of the PV system.

The relation (6) determines the number of strings connected in parallel given by the ratio between the input current of the inverter and the short-circuit current of the module used in the photovoltaic system [24].

$$
\text { Fstring }=\frac{\mathrm{I}_{\mathrm{max}, \mathrm{INVERSOR}}}{\mathrm{I}_{\mathrm{SC}, \text { MÓDULO }}}
$$

At where:

Fstring: Maximum number of rows that can be associated in parallel.

I_ (max, INVERTER): Is the maximum input current of the inverter found on the manufacturer's sheet, at data input, 18A.

I_ (SC, MODULE): It is the short-circuit current of a row of "strings" which is always equal to the short-circuit current of the Isc module, found on the manufacturer's datasheet in Electrical Data, 8.71 A.

The maximum number of modules that can be connected in series by the PV array is given by the ratio (7) which is the ratio between the maximum input voltage of the inverter, which must not be exceeded, by the open circuit voltage of the module corrected at Low temperatures [19].

The result found should be rounded down.

$$
M_{\text {SérieMax }}=\frac{U_{D C M A X, I N V E R S O R}}{V_{\text {Oc,MÓDULO_CORRIGIDO }}}
$$

At where:

M_seriesMax: Maximum number of modules connected in series.

U_ (DCMAX, INVERTER): It is the maximum input voltage of the inverter [V] which is $500 \mathrm{~V}$.

$\mathrm{V}_{-}$(oc, MODULE_CURED): It is the open circuit voltage of the module [V] which is $39.5 \mathrm{~V}$.

After correction of the maximum voltage of the module, the minimum number of modules that can be connected in series by the photovoltaic array through the ratio [20] per [19]. The result found should be rounded off for more.

$$
M_{M i m, M P P T}=\frac{U_{M i n M P P T, I N V E R S O R}}{V_{M P P, M O ́ D . C O R R I G I D O}}
$$

At where:

M_ (Me, MPPT): Minimum number of modules connected in series.

U_ (MinMPPT, INVERTER): Minimum inverter power, $150 \mathrm{~V}$.

V_ (MPP, CURRENT MODULE): Voltage in Maximum power of the corrected photovoltaic module, $23.6 \mathrm{~V}$.

\section{RESULTS AND DISCUSSIONS}

The photovoltaic system connected to the electric grid is designed to be installed in the Holy Land of Pará with the following geographic coordinates, at a latitude $-1^{\circ} 22^{\prime} 47$ " and Longitude -48 - 28 '47 "'in order to meet a consumption requirement Of $337 \mathrm{kWh}$ / month will require according to ratio (2) an amount of 10 photovoltaic modules of $250 \mathrm{~W}$.

The inverter used must have a minimum power capacity according to the ratio (1) of 2,6931 KW. Therefore, in the following simulations it was decided to use a Fronius 3.0 inverter. 
Table 2 shows the variation of modules to verify the voltage range ideal for the proper operation of the inverter.

Note that the data provided in the blue strip in table 02 represent the number of modules that can be connected in series respecting the voltage limits of the inverter. The minimum number of modules connected in series according to the ratio [25] are 7 modules and the maximum number of modules connected in series according to the ratio (7) are 11 modules. As the number of modules needed to meet the consumption of the residence in study are 10 modules, it was then decided to organize the 10 modules connected in series.

Table 2: Ideal inverter voltage range.

\begin{tabular}{|c|c|c|c|c|}
\hline \multicolumn{5}{|c|}{ Number of Modules Connected in Series } \\
\hline Qodules & $\begin{array}{l}\text { Voltage } \\
\text { VMPP } \\
\text { arrangement }\end{array}$ & $\begin{array}{l}\text { VMMP } \\
\text { Correction }\end{array}$ & Vca & $\begin{array}{l}\text { Vca } \\
\text { Correction }\end{array}$ \\
\hline 1 & 30,7 & 23,6083 & 37,8 & 39,501 \\
\hline 2 & 61,4 & 47,2166 & 75,6 & 79,002 \\
\hline 3 & 92,1 & 70,8249 & 113,4 & 118,503 \\
\hline 4 & 122,8 & 94,4332 & 151,2 & 158,004 \\
\hline 5 & 153,5 & 118,0415 & 189 & 197,505 \\
\hline 6 & 184,2 & 141,6498 & 226,8 & 237,006 \\
\hline 7 & 214,9 & 165,2581 & 264,6 & 276,507 \\
\hline 8 & 245,6 & 188,8664 & 302,4 & 316,008 \\
\hline 9 & 276,3 & 212,4747 & 340,2 & 355,509 \\
\hline 10 & 307 & 236,083 & 378 & 395,01 \\
\hline 11 & 337,7 & 259,6913 & 415,8 & 434,511 \\
\hline 12 & 368,4 & 283,2996 & 453,6 & 474,012 \\
\hline 13 & 399,1 & 306,9079 & 491,4 & 513,513 \\
\hline 14 & 429,8 & 330,5162 & 529,2 & 553,014 \\
\hline 15 & 460,5 & 354,1245 & 567 & 592,515 \\
\hline 16 & 491,2 & 377,7328 & 604,8 & 632,016 \\
\hline 17 & 521,9 & 401,3411 & 642,6 & 671,517 \\
\hline 18 & 552,6 & 424,9494 & 680,4 & 711,018 \\
\hline 19 & 583,3 & 448,5577 & 718,2 & 750,519 \\
\hline 20 & 614 & 472,166 & 756 & 790,02 \\
\hline 21 & 644,7 & 495,7743 & 793,8 & 829,521 \\
\hline 22 & 675,4 & 519,3826 & 831,6 & 869,022 \\
\hline 23 & 706,1 & 542,9909 & 869,4 & 908,523 \\
\hline
\end{tabular}

Source: Authors, (2017).

Under these conditions, the simulations were carried out using the software PVSOL PREMIUM 2017 in which the following results were obtained:

The photovoltaic generator has power of $2.5 \mathrm{KWp}$, which will occupy an area for installation of $16.3 \mathrm{~m} 2$.

The overall solar irradiation incident on the plane of the modules is $1821.4 \mathrm{KWh} / \mathrm{m}^{2}$.

The amount of $\mathrm{CO}_{2}$ emissions avoided in the atmosphere is $2178 \mathrm{~kg} /$ year. Figure 11 shows the overall irradiance per generator area throughout the year.

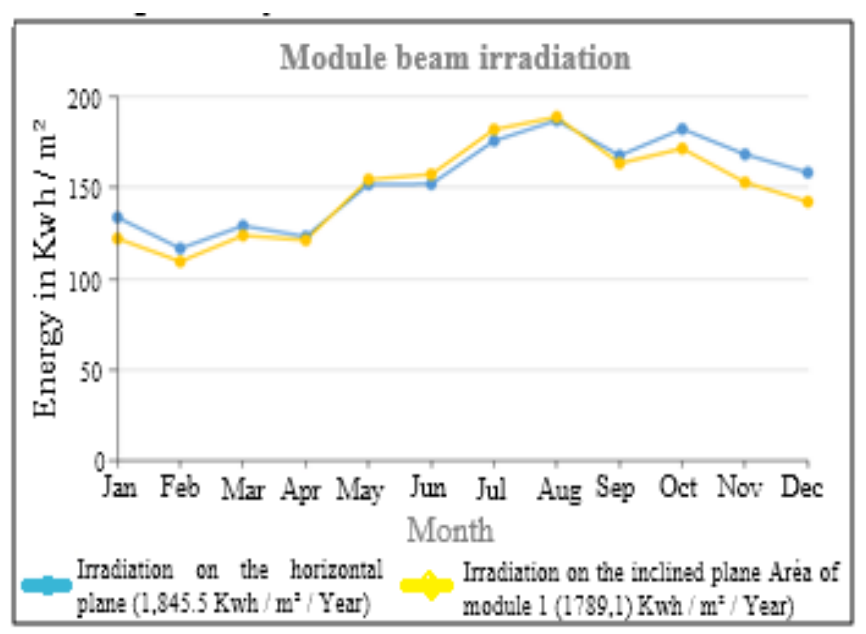

Figure 11: Irradiation by module area Source:[21].

Figure 12 shows the temperature variation per module area during the year.

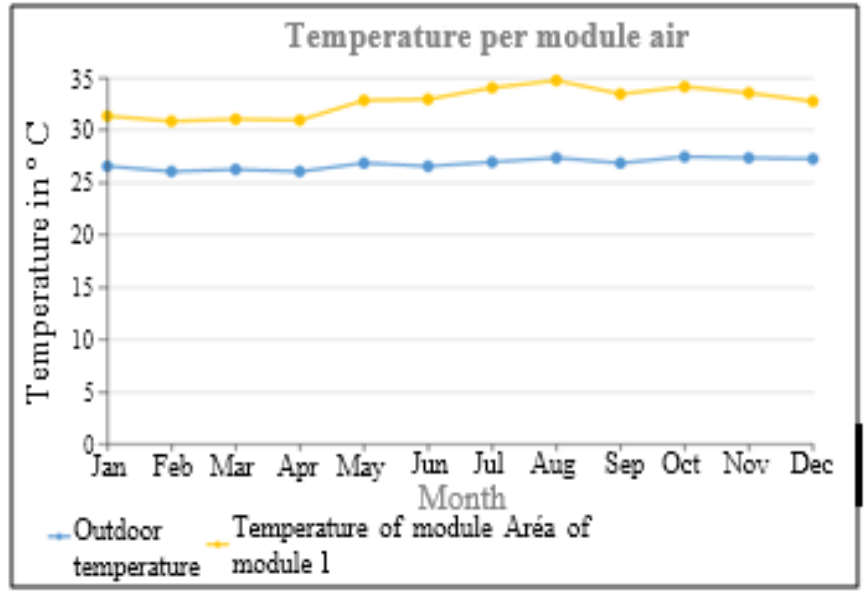

Figure 12: Temperature per module area.

Source: [21].

The performance (PR) of the system is $79.4 \%$ with annual yield of $1452.13 \mathrm{KWh} / \mathrm{KWp}$. The figure in figure 13 shows the result.

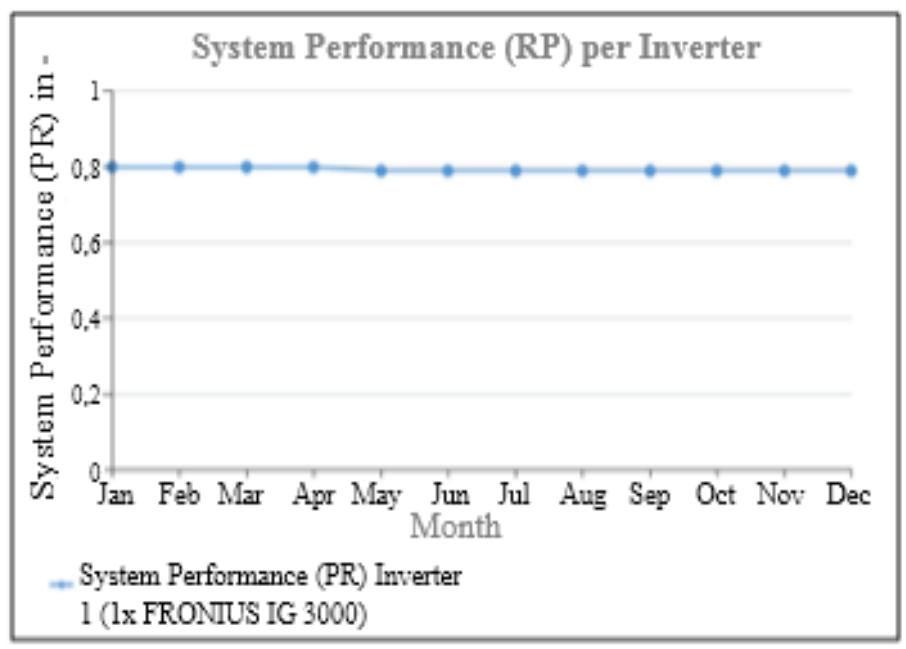

Figure 13: Performance (PR) of the Photovoltaic System. Source: [21]. 
Figure 14 shows the monthly forecast of the system performance. It is observed that the best yields occur in the months of June, July, August, September, October and November.

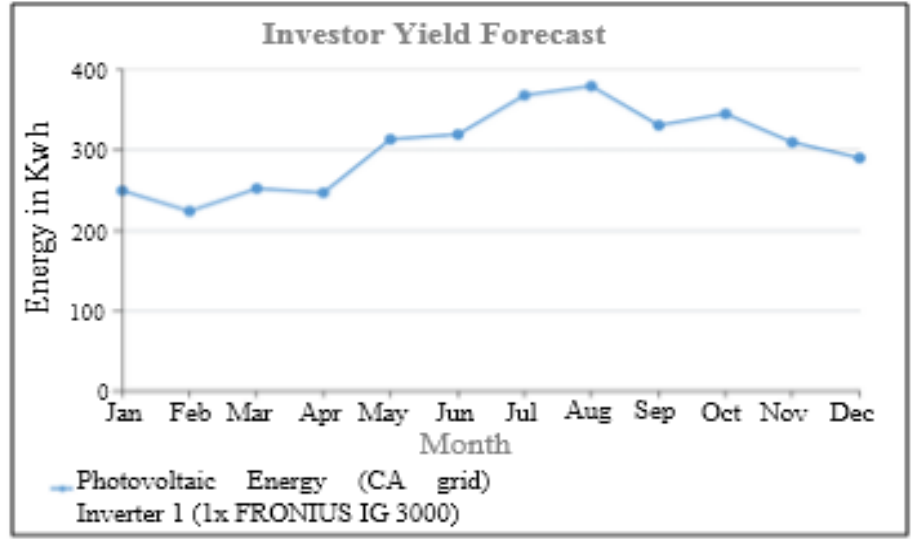

Figure 14: Monthly Income Forecast.

Source: [21].

Figure 15 shows a comparison between the monthly consumption of the residence and the photovoltaic energy produced by the system during the year.

It is observed in this figure that the months of July and August present the best photovoltaic energy production. The photovoltaic generator will deliver the grid $3630 \mathrm{KWh} /$ year consuming only $416 \mathrm{KWh}$ / year from the grid.

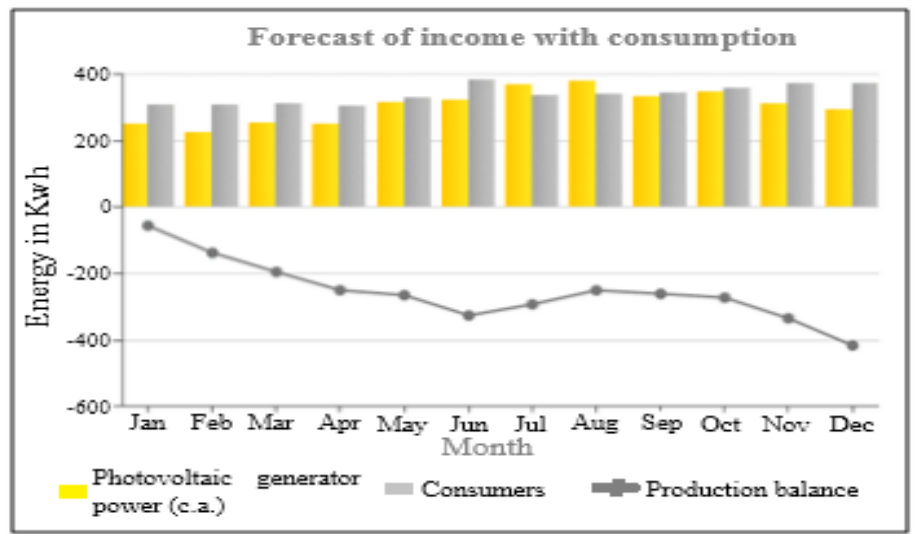

Figure 15: Monthly Photovoltaic Energy production forecast. Source: [21].

According to the historical data of the energy consumption of the study residence, it is observed that the residence consumes $4041 \mathrm{KWH} /$ year paying the concessionaire the equivalent of $\mathrm{R} \$ 2987,64$.

With the implementation of photovoltaic system connected to the electric grid the consumption will be $1200 \mathrm{KWh} /$ year corresponding to $\mathrm{R} \$ 863.26$. The savings after the implementation of the system is $2841 \mathrm{KWh} /$ year corresponding to $\mathrm{R} \$ 2124,39$.

The economy with the system is shown in figure 16 . In this it is observed that the price of the energy to be paid to the concessionaire reduced, providing to the user a reduction in the cost of the energy consumption.

It is also noted that in any of the months the user will not pay the concessionaire, since he pays the concession fee of the network that in this system is three-phase which must be paid $100 \mathrm{KWH} /$ month for the use of the electric network.

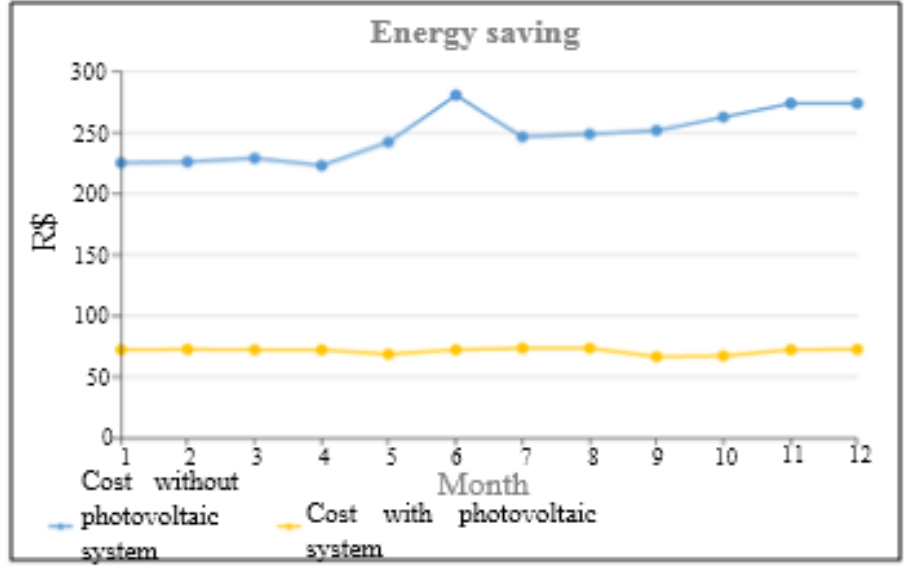

Figure 16: Monthly economics with systemimplementation. Source: [21]

Figure 17 shows the payback time of the investment that is 9 years.With return rate of $10.73 \%$.

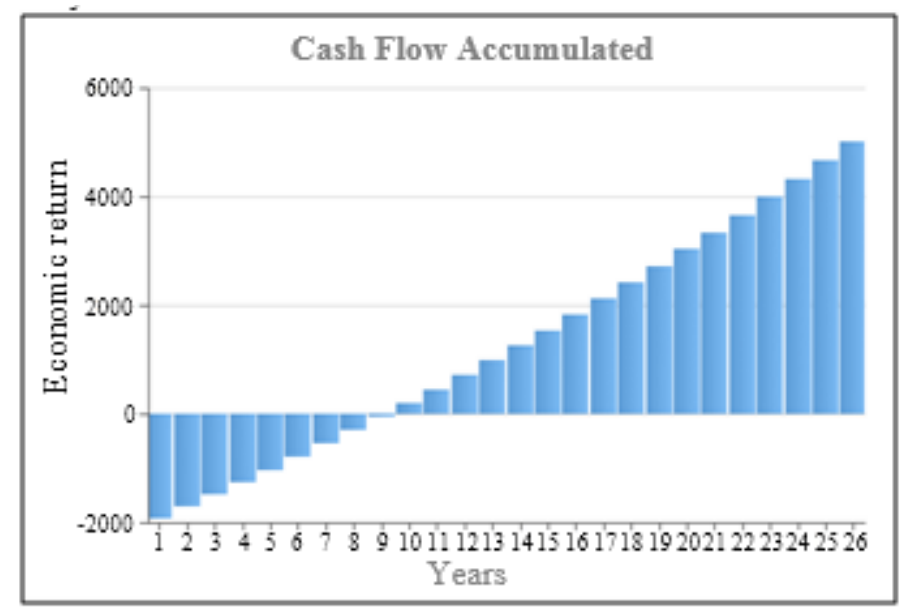

Figure 17: Return on Investment.

Source: [21].

\section{CONCLUSION}

The simulations with the PVSOL PREMIUM 2017 software provided a comprehensive view of the design of the photovoltaic system connected to the distribution grid.

For the simulations performed in the geographical conditions of Terra Santa, in the interior of Pará, with the geographical coordinates of Latitude $-1^{\circ} 22^{\prime} 47$ " and Longitude $48^{\circ} 28^{\prime} 47$ ". According to historical data of the residence's energy consumption that is $4041 \mathrm{KWh} /$ year with payment of annual invoice of $\mathrm{R} \$ 2$ 2987.64. According to the simulations, the implementation of the photovoltaic systemallowed the energy bill to be reduced by approximately $70 \%$ of the value per year, corresponding to $2841 \mathrm{KWh} /$ year, corresponding to the consumption of $\mathrm{R} \$ 2124.39$ per year.

Therefore, the simulations show that photovoltaic systems connected to the distribution grid complement the energy consumption savings satisfactorily. In addition to contributing to the reduction of emissions of greenhouse gases, as a source of renewable energy. In this study the reduction of $\mathrm{CO} 2$ emissions was $2178 \mathrm{~kg} /$ year.

Therefore, the use of photovoltaic renewable energy generation is an alternative to contribute to the reduction of the 
electric energy tariff and to improve the air quality of the atmosphere by reducing the $\mathrm{CO} 2$ gases.

The PVSOL PREMIUM 2017 software used in this research for the design of the photovoltaic system contributed greatly to the best evaluation of photovoltaic systems giving a vision of photovoltaic energy productivity, economy with system implementation, system efficiency and economic return on investment.

\section{ACKNOWLEDGMENTS}

We thank all those who directly or indirectly collaborated with this research. CELPA for providing the data to start the work. We thank the partnership between the University Center of NorthUNINORTE and the Federal University of Pará-UFPA for providing research fields related to the use of renewable resources in the North region, encouraging the population to seek new sources of energy production, always aiming at the quality of environment.

\section{REFERENCES}

[1] PRODIST (2016). "Procedimentos de Distribuição de Energia Elétrica no Sistema Elétrico Nacional. ANEEL, versão 9.":2016.

\section{[2] https://maps.nrel.gov/swera. Acesso em 17.05.2017.}

[3] Aramizu, J. Modelagem e análise de desempenho de um sistema fotovoltaico em operação isolada e em paralelo com uma rede de distribuição de energia elétrica, Universidade de São Paulo (USP). 2010.

[4] Marinoski, D. L., I. T. Salamoni and R. Rüther (2004). Prédimensionamento de sistema solar fotovoltaico: estudo de caso do edifício sede do CREA-SC. Conferência Latino-Americana de Construção Sustentável. São Paulo, Brasil.

[5] Varella, F., C. K. N. Cavaliero and E. Silva (2008). "Energia solar fotovoltaica no Brasil: Incentivos regulatórios." Revista Brasileira de Energia 14(1): 9-22.

[6] Shayani, R. A., M. A. G. d. Oliveira and I. d. T. Camargo (2006). Comparação do custo entre energia solar fotovoltaica e fontes convencionais. Congresso Brasileiro de Planejamento Energético (V CBPE). Brasília.

[7] Proença, E. (2007). "A Energia Solar Fotovoltaica em Portugal." Instituto Superior Técnico, Universidade Técnica de Lisboa.

[8] Castro, R. (2011). "Uma introdução às energias renováveis: eólica, fotovoltaica e mini-hídrica." Lisboa: Instituto Superior Técnico.

[9] Cabral, I. and R. Vieira (2012). Viabilidade econômica $\mathbf{x}$ viabilidade ambiental do uso de energia fotovoltaica no caso brasileiro: uma abordagem no período recente. III Congresso Brasileiro de Gestão Ambiental.

[10] Rampinelli, G. and A. Krenzinger (2009). "Descrição de um Programa Computacional de Simulação de Sistemas Fotovoltaicos Conectados à Rede Elétrica de Distribuição." Avances en Energías Renovables y Medio Ambiente 13: 04.2104.28 .
[11] Behenck, I. S. (2011). Estudo Comparativo da Viabilidade de Sistemas Fotovoltaicos Conectados à Rede, Através do Software Homer, Universidade Federal do Rio de Janeiro.

[12] Ali, N. M.; Rafat, N. H. Modeling and simulation of nanorods photovoltaic solar cells: A review. Renewable and Sustainable Energy Reviews, v. 68, p. 212-220, 2017.

[13] Fath, K., J. Stengel, W. Sprenger, H. R. Wilson, F. Schultmann e T. E. Kuhn (2015). "A method for predicting the economic potential of (building-integrated) photovoltaics in urban areas based on hourly Radiance simulations." Solar Energy 116: 357370 .

[14] De Lima, L. C., L. de Araújo Ferreira and F. H. B. de Lima Morais (2017). "Performance analysis of a grid connected photovoltaic system in northeastern Brazil." Energy for Sustainable Development 37: 79-85.

[15] Souza, A. C. d. (2016). "Análise dos impactos da geração distribuída por fonte solar fotovoltaica na qualidade da energia elétrica."

[16]_http://energiatecsolar.com.br. Acesso em 15 de abril de 2017.

[17] dos Reis, L. B. Geração de energia elétrica. Editora Manole. 2015.

\section{[18] http://cresesb.cepel.br. Acesso em 21 Abril de 2017.}

[19] De Martino Jannuzzi, G., F. K. Varella and R. D. M. Gomes (2009). "Sistemas fotovoltaicos conectados à rede elétrica no Brasil: panorama da atual legislação." International Energy Initiative para an América Latina (IEI-LA) e Universidade Estadual de Campinas (Unicamp).

[20] Gnoatto, E., Y. Ferruzzi and R. P. Ricieril (2004). "Performance of panel fotovoltaico in an isolated system." Procedings of the 5th Encontro de Energia no Meio Rural.

[21] Simulações PVSOL PREMIUM. 2017.

[22] Freitas, S. S. A. Dimensionamento de sistemas fotovoltaicos. Instituto Politécnico de Bragança, Escola Superior de Tecnologia e de Gestão. 2008.

[23] www.axitecsolar.com/pt/modulos-solares.html. Folha do fabricante AXITEC. Acesso em 22 de 2017.

[24] Udaeta, M. E. M., J. L. d. O. Bernal and G. P. S. Sampaio (2014). "Relatório Técnico Científico : Dimensionamento de um Sistema Fotovoltaico Residencial Zero-Energia ": 32.

[25] NBR10899 (2013). "Energia Solar FotovoltaicaTerminologia." 11. 